\title{
Prevalence and accompanying factors for postpartum depression symptoms
}

\author{
Postpartum depresyon belirtilerinin yaygınlığı ve eşlik eden faktörler
}

\author{
iDGulay Pamuk ${ }^{\mathrm{a}}$, iD Yusuf Adnan Guclu ${ }^{\mathrm{b}}$
}

${ }^{a}$ Buca No. 12 Firat Family Health Center, Izmir, Turkey

${ }^{\mathrm{b}}$ Department of Family Medicine, Tepecik Training and Research Hospital, University of Health Sciences, Izmir, Turkey

\begin{abstract}
Introduction: Postpartum depression [PPD] is a disorder that starts during pregnancy or within the first four weeks postpartum with comorbid major depressive symptoms and is an important cause of morbidity and mortality for both the mother, and the baby. Depression surveys aimed to identify the at-risk population, during pregnancy and postpartum, may prove to be useful in preventing this disorder, which may have serious consequences. The present study aimed to determine the incidence of PPD symptoms in mothers with babies aged 1-18 months and to investigate the parameters affecting the occurrence of PPD.

Methods: The study was designed as a descriptive, cross-sectional study including 302 mothers with 1-18-month-old babies registered at Firat 12 Family Health Center (FHC) in Buca, Izmir, between 1 November 2020 and 28 February 2021 The study investigated the sociodemographic characteristics of the cases, marital relations, reproductive health, recent birth history, and development of depression as detected using the Edinburgh Postpartum Depression Scale (EPDS).

Results: The mean age of the 302 participants included in the study was $29.49 \pm 5.18$ years, where the mean score from the EPDS scale was $6.43 \pm$ 6.06. As a result of the study, the risk of occurrence of PPD was 14.6\%. In the present research, the factors associated with increased risk of PPD included a history of personal and familial psychiatric disorders, poor communication with the partner, partner's irregular employment status, psychiatric disorders during the previous birth, lack of regular monitoring during pregnancy, and lack of a helper in baby care ( $<<0.050$ ).

Conclusion: In particular, the practices that may reduce the risk of PPD include regular follow-up of the pregnancies of the women with a personal or familial history of psychiatric disorders or with psychiatric problems during their previous birth, questioning their family relationships during this process, referring them to a psychologist, psychiatrist or family counselor if necessary, and offering postpartum family support to mothers in baby care.
\end{abstract}

Keywords: Postpartum period, prevalence, depression, risk factors

\section{$\ddot{O} z$}

Giriş: Postpartum depresyon [PPD], hamilelik dönemi veya doğumdan sonraki ilk dört hafta içinde başlayan, majör depresif bulgularla seyreden bir hastalık olup, anne ve bebek için mühim bir morbidite ve mortalite sebebidir. Risk altındaki nüfusu belirlemek için, gebelikte ve doğum sonrası dönemde depresyon taramaları yapmak, ciddi sonuçlar doğurabilen bu hastalığı önlemek açısından faydalı olabilir. Bu çalışmada, 1-18 aylık bebeği olan annelerde, PPD belirti sıklığının belirlenmesi ve PPD gelişimini etkileyen parametrelerin incelenmesi amaçlamıştır.

Yöntem: Araştırmamız, 1 Kasım 2020- 28 Şubat 2021 tarihleri arasında, İzmir Buca 12 Nolu Fırat Aile Sağlığı Merkezinde (ASM) kayıtlı, 1-18 aylık bebeği olan 302 anneyi kapsayan, tanımlayıcı, kesitsel tipte bir çalışmadır. Olguların Sosyodemografik özellikleri, evlilik ilişkileri, üreme sağlığı, son doğum öyküsü ve Edinburgh Doğum Sonrası Depresyon Ölçeği (EDSDÖ) ile belirlenen depresyon gelişme durumu incelenmiştir.

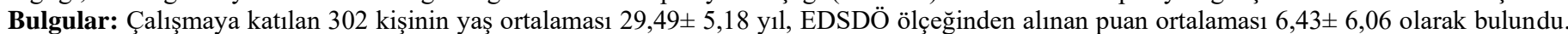
Çalışmamız sonucunda, PPD gelişme riski \%14,6 oranında bulundu. Araştırmamızda kendisinde ve soy geçmişinde psikiyatrik hastalık öyküsü olmasının, eş ile iletişimin kötü olmasının, eşin düzenli bir işte çalışmıyor oluşunun, önceki doğumda psikiyatrik hastalık varlığının, gebelikte düzenli takip edilmemenin ve bebek bakımına yardım eden birinin bulunmamasının PPD riskini arttırdığ 1 belirlendi $(\mathrm{p}<0.050)$.

Sonuç: Özellikle kendisinde, ailesinde veya önceki doğumunda psikiyatrik hastalık öyküsü olan kadınların gebeliklerinin düzenli olarak takip edilmesi, bu süreçte aile ilişkilerinin sorgulanması, gerekliyse psikolog, psikiyatrist ya da aile danışmanına yönlendirilmesi ve bebek bakımı açısından, annelere doğum sonrası aile desteğinin önerilmesi PPD riskini azaltabilecek uygulamalar arasında yer alabilir.

Anahtar Kelimeler: Postpartum dönem, prevalans, depresyon, risk faktörleri

\begin{tabular}{|r|c|c|c|c|}
\hline \multicolumn{1}{|c|}{ Received } & Accepted & Published Online & Corresponding Author & E-mail \\
\hline November 17, 2021 & February 25, 2022 & March 17, 2022 & Gulay Pamuk, M.D. & $\underline{\text { dr.g.pamuk@ @otmail.com }}$ \\
\hline Correspondence & Dr. Gülay Pamuk, Frrat Mah. 272/9 Sok. No:2/3 Dalyan Sitesi C blok Buca, İzmir-Turkey \\
\hline doi & https://doi.org/10.22391/fppc.1024922 \\
\hline
\end{tabular}




\section{Key Points}

1. The incidence of PPD symptoms across the research area is $14.6 \%$.

2. The factors associated with increased PPD risk are history of depression, history of PPD, and familial history of depression.

3. Other risk factors for PPD are lack of regular monitoring and follow-up during pregnancy, lack of communication with the partner, partner's irregular employment status, and the lack of a helper in baby care.

\section{Introduction}

Childbirth is a challenging and exhaustive process. A number of hormonal, physical, emotional, and psychological changes occur during the pregnancy period. Significant changes arise in the family and the social relations of the mother. Depressive symptoms may occur as a result of the individual's inability to go through this process in a healthy way and to cope with fatigue and stress, and inadequate support from family, relatives or healthcare providers. Depression is a prevalent complication during pregnancy and after delivery [1]. The rate of patients, who experience the first period of depression during the postpartum period and during pregnancy, is approximately $40 \%$ and $33 \%$, respectively [2]. Depressive symptoms that start during pregnancy are among the strongest determinants of the Postpartum depression [PPD] [3,4]. PPD diagnosis is based on whether the depressive symptoms of the mother or expectant mother meet the major depression criteria. American Psychiatric Association's Diagnostic and Statistical Manual of Mental Disorders, fifth edition (DSM-5) considers PPD in a patient in case of a major depressive period with peripartum onset and does not refer to PPD as a separate condition [5].

Determinants of postpartum depression include perinatal anxiety, history of psychiatric disorders, various sources of stress in patients' life, perceived social isolation and low self-esteem [3,4]. It was shown that socioeconomic status and obstetric complications were also associated with the occurrence of PPD [3]. Other risk factors include a history of physical abuse, postpartum medical complications and a family history of PPD [6,7]. Rapid decline in estrogen, progesterone and cortisol levels combined with sources of psychosocial stress was suggested to increase the overall risk of PPD, especially in women with a personal or familial history of psychiatric disorders [8]. Detecting patients at risk of PPD by means of surveys may prove to be useful in preventing morbidity and mortality associated with the disorder. The present study aimed, to determine the incidence of PPD symptoms in mothers with babies aged 1-18 months and to investigate the parameters affecting the occurrence of PPD.

\section{Methods}

Designed as a descriptive, cross-sectional research, the present study was performed at Firat Family Health Center (FHC) in Buca, Izmir, between 1 November 2020 and 28 February 2021. The target population of the study consisted of approximately 500 mothers with 1-18-month-old babies registered at 9 family medicine units in the FHC. 302 mothers, who were reached out and approved the Volunteer Consent Form were included in the study. After the participants were briefed about the purpose of the study, they were asked to respond a total of 58 items, including sociodemographic characteristics, marital relations, reproductive health, last birth history and Edinburgh postpartum depression scale [EPDS] by face-to-face questionnaire method. The incidence of PPD risk and the comorbid factors were investigated based on the responses of the participants. An EPDS cutoff score of equal to or greater than 13 was recommended to decide whether patients were at risk of developing PPD [9,10]. Accordingly, the EPDS cutoff score was taken as 13 for the purposes of the present study.

\section{Ethics Committee and Institutional Approvals}

Relevant approval required to conduct the study was provided in the form of written permission by the Non-Interventional Ethics Committee of the University of Health Sciences (SBU) Izmir Tepecik Health Application Research Center, dated 23.07.2020 and Decision No: 2020/9-5; and by the Izmir Provincial Health Directorate dated 27.01.2021 and No. E-36026262-702.99.

\section{Statistical Analyses}

A database was created in the Statistical Package for the Social Sciences (SPSS) Version 21.0 software program and the frequency, percentage, mean, standard deviation, median, minimum and maximum values of the data were calculated for the purpose of analyses in the scope of the study. Pearson Chi-square test and Fisher's Exact test were employed for the intergroup comparison of categorical variables. As regards the binary comparisons of continuous numerical variables, the Shapiro-Wilk test was used to analyze the hypothesis of normal distribution and it was decided to use either the parametric or non-parametric tests. As regards the comparison of numerical data between binary groups, the Independent Samples to test was used in cases, where normal distribution hypothesis was met, and the Mann Whitney U test was used where there was no normal distribution. The logistic regression analysis was used for the multivariate analyses aimed to determine the factors, which had an effect on depression. Bar and box-line charts were used in the graphical presentation of numeric variables. A p value of $<0.050$ was considered statistically significant for all the analyses.

\section{Results}

Out of a total of 302 participants included in our study, 51\% were high school/university graduates, $64.6 \%$ were unemployed and $99 \%$ were married. $16.2 \%$ of the participants did not have social security, where $90.4 \%$ did not receive social support. $7.9 \%$ of the participants had personal psychiatric disorders, $11.9 \%$ had a familial history of psychiatric disorders, $10.9 \%$ had at least one chronic disease and $18.9 \%$ smoked. The top 3 professions of the participants were as follows: $73.5 \%$ were housewives, $4.6 \%$ educational professionals and $3 \%$ healthcare professionals. The top 3 occupations of the participants' spouses were as follows: $21.9 \%$ workers, $21.5 \%$ self-employed, and $17.5 \%$ service personnel in order of frequency. $21.9 \%$ of the mothers reported that they had an arranged marriage, $6.6 \%$ had their second marriage, $20.9 \%$ had consanguineous marriage and $1.3 \%$ reported poor communication with their spouses. $44.7 \%$ of the participants reported premenstrual syndrome (PMS) and $2.3 \%$ psychiatric disorders at previous births. $24.2 \%$ of the participants reported that their pregnancy was not planned, $7 \%$ of the participants reported that the sex 
of the baby was important, $9.3 \%$ of the participants reported that the sex of their baby was not the sex they wanted, $97.7 \%$ of the participants reported that they were regularly monitored during pregnancy and $18.9 \%$ of the participants reported that they had problems during their pregnancy. In the present study, 44 mothers (14.6\%) were at risk of developing depression based on the EPDS scores. Table 1 shows in detail the distribution of certain characteristics related to delivery and postpartum and the EPDS scores.

Table 1. Distribution of certain characteristics of participants related to delivery and postpartum and the EPDS scores

\begin{tabular}{|c|c|c|}
\hline & $\mathbf{n}$ & $\%$ \\
\hline \multicolumn{3}{|l|}{ Birth time } \\
\hline Mature & 256 & 84.8 \\
\hline Premature & 35 & 11.6 \\
\hline Postmature & 11 & 3.6 \\
\hline \multicolumn{3}{|l|}{ Type of delivery } \\
\hline Normal & 117 & 38.7 \\
\hline Caesarean section & 185 & 61.3 \\
\hline \multicolumn{3}{|l|}{ Place of birth } \\
\hline Home & 1 & 0.3 \\
\hline Hospital & 301 & 99.7 \\
\hline \multicolumn{3}{|l|}{ Complications in the mother } \\
\hline Yes & 10 & 3.3 \\
\hline No & 292 & 96.7 \\
\hline \multicolumn{3}{|l|}{ Complications in the baby } \\
\hline Yes & 14 & 4.6 \\
\hline No & 288 & 95.4 \\
\hline \multicolumn{3}{|l|}{ Breastfeeding status } \\
\hline Still breastfeeding & 240 & 79.5 \\
\hline Never breastfed & 19 & 6.3 \\
\hline Previously breastfed & 43 & 14.2 \\
\hline \multicolumn{3}{|l|}{ Do you think babysitting is difficult? } \\
\hline Easy & 71 & 23.5 \\
\hline Moderate & 152 & 50.3 \\
\hline Hard & 79 & 26.2 \\
\hline \multicolumn{3}{|l|}{ Does anyone help with babysitting? } \\
\hline Yes & 117 & 38.7 \\
\hline No & 185 & 61.3 \\
\hline \multicolumn{3}{|l|}{ Do you think you're a good mother? } \\
\hline Yes & 297 & 98.3 \\
\hline No & 5 & 1.7 \\
\hline \multicolumn{3}{|l|}{ Risk of Depression } \\
\hline Yes (EPDS score $\geq 13$ ) & 44 & 14.6 \\
\hline No (EPDS score <13) & 258 & 85.4 \\
\hline
\end{tabular}

$61.3 \%$ of the participants reported delivery by caesarean section, $3.3 \%$ of the participants reported complications ( 8 cases of hypertension, 2 placenta adhesion/ bleeding, 1 difficult birth), $4.6 \%$ had babies with complications (6 cases of respiratory distress, 4 premature birth, 1 congenital jaundice, 1 cord filling, 1 meconium aspiration, and 1 hydrocephalus). Table 2 shows the age characteristics, obstetric characteristics and EPDS score distribution.

Table 2. The participants' age characteristics, obstetric characteristics and EPDS score distribution

\begin{tabular}{lrr}
\hline & \multicolumn{1}{c}{ Mean \pm SD } & Median (min- max) \\
\hline Age, years & $29.49 \pm 5.18$ & $29(19-44)$ \\
Age of marriage, years & $22.68 \pm 4.41$ & $22(1-40)$ \\
Spouse's age, years & $33.49 \pm 5.58$ & $33(21-51)$ \\
Pregnancy & $2.32 \pm 1.36$ & $2(1-9)$ \\
Child Birth & $1.84 \pm 0.97$ & $2(0-8)$ \\
Miscarriage & $0.27 \pm 0.66$ & $0(0-6)$ \\
Abortion & $0.14 \pm 0.43$ & $0(0-3)$ \\
Stillbirth & $0.06 \pm 0.24$ & $0(0-1)$ \\
Children alive & $1.88 \pm 0.97$ & $2(0-8)$ \\
\multicolumn{1}{c}{ EPDS total score } & $6.43 \pm 6.06$ & $5(0-30)$ \\
\hline
\end{tabular}

SD: Standard Deviation, Min: Minimum, Max: Maximum

The mean age of the individuals was $5.18 \pm 29.49$, where the mean marriage age $22.68 \pm 4.41$. The mean EPDS score was $6.43 \pm 6.06$.

There was no significant relationship between the sociodemographic characteristics of the individuals and the occurrence of depression symptoms $(\mathrm{p}>0.050)$.

The frequency of personal and familial psychiatric disorders and smoking status in mothers at risk of developing depression are shown in detail in Table 3.

Table 3. A comparison between the risk of depression and the participants' history of psychiatric disorders, chronic diseases, and smoking status

\begin{tabular}{|c|c|c|c|c|c|}
\hline & \multicolumn{4}{|c|}{ Risk of Depression } & \multirow{3}{*}{$\mathbf{p}$} \\
\hline & \multicolumn{2}{|c|}{ No $(n=258)$} & \multicolumn{2}{|c|}{ Yes $(n=44)$} & \\
\hline & $\mathbf{n}$ & $\%$ & $\mathbf{n}$ & $\%$ & \\
\hline \multicolumn{6}{|l|}{ Psychiatric disorder } \\
\hline Yes & 9 & 37.5 & 15 & 62.5 & \multirow{2}{*}{$<0.001$} \\
\hline No & 249 & 89.6 & 29 & 10.4 & \\
\hline \multicolumn{6}{|l|}{ Chronic disease } \\
\hline Yes & 24 & 72.7 & 9 & 27.3 & \multirow{2}{*}{0.028} \\
\hline No & 234 & 87.0 & 35 & 13.0 & \\
\hline \multicolumn{6}{|c|}{ Familial history of psychiatric disorders } \\
\hline Yes & 22 & 61.1 & 14 & 38.9 & \multirow{2}{*}{$<0.001$} \\
\hline No & 236 & 88.7 & 30 & 11.3 & \\
\hline \multicolumn{6}{|l|}{ Smoking } \\
\hline Yes & 44 & 77.2 & 13 & 22.8 & \multirow{2}{*}{0.051} \\
\hline No & 214 & 87.3 & 31 & 12.7 & \\
\hline
\end{tabular}

Mothers at risk of developing depression had a statistically significantly higher incidence of personal and familial history of psychiatric disorders $(\mathrm{p}=0.001)$ and comorbid chronic diseases $(\mathrm{p}=0.028$ ). The risk of developing depression in patients with and without psychiatric disorders was found as $62.5 \%$ and $10.4 \%$, respectively. Participants with a history of psychiatric disorder had a statistically significantly higher risk of developing depression $(p<0.001)$. The risk of developing depression in patients with and without a history of familial psychiatric disorders was found as $38.9 \%$ and $11.3 \%$, respectively. Participants with a history of familial psychiatric disorders had a statistically significantly higher risk of developing depression $(\mathrm{p}<0.001)$.

Second marriage ( $\mathrm{p}=0.007$ ), poor communication with the spouse and spouse's family $(\mathrm{p}=0.001)$, marital dissatisfaction $(\mathrm{p}=0.004)$, the lack of regular employment of the spouse and domestic violence $(\mathrm{p}=0.001)$ were statistically significantly more prevalent in the mothers at risk of developing depression. 
The risk of developing depression was statistically significantly higher in the participants with poor communication with their spouses $(\mathrm{p}=0.004)$. The participants with spouses with and without regular employment had a risk of developing depression at a rate of $11.1 \%$ and $31 \%$, respectively. The risk of developing depression was statistically significantly higher in the participants with a partner without a regular job $(p=0.001)$. Among mothers at risk of developing depression, the prevalence of the PMS ( $p=0.038)$ and psychiatric problems during the previous birth was statistically significantly higher $(\mathrm{p}=0.001)$. The risk of developing depression in participants with and without psychiatric problems during the previous birth was at a rate of $57.1 \%$ and $13.6 \%$, respectively. The prevalence of developing depression in the participants with psychiatric problems at previous birth was statistically significantly higher $(\mathrm{p}=0.001)$. The frequency of regular follow-up during pregnancy was statistically significantly lower $(\mathrm{p}<0.001)$, where the frequency of complications during pregnancy was statistically significantly higher in participants at risk of developing depression $(\mathrm{p}=0.005)$.

There was a risk of developing depression in $13.6 \%$ of those who went to regular follow-up during pregnancy and $57.1 \%$ of those who did not. The risk of developing depression was statistically significantly higher in those who did not have regular follow-up during pregnancy $(\mathrm{p}=0.001)$. Mothers at risk of developing depression had statistically significantly less frequently received help for baby care $(\mathrm{p}=0.018)$.

An assessment of effects of the risk factors associated with postpartum depression in single-variable analyses by the Backward logistic regression analysis, indicated that the model was significant $(\mathrm{p}<0.001)$, and the model had a medium R-squared (coefficient of determination) value $(43.5 \%)$. In the model, history of psychiatric disorders, familial history of psychiatric disorders, poor communication with the partner, lack of regular employment of the partner, history of psychiatric problems during the previous birth, lack of regular follow-up during pregnancy and lack of a helper in baby care increased the risk of postpartum depression $(\mathrm{p}<0.050)$. These results are shown in Table 4.

Table 4. Factors increasing risk in individuals at risk of developing postpartum depression, multivariate logistic regression analysis (Backward stepwise, step10)

\begin{tabular}{|c|c|c|c|c|}
\hline & $\mathbf{p}$ & Odds Ratio & 95\% Confid & interval \\
\hline History of psychiatric disorder & $<0.001$ & 9.406 & 3.030 & -29.203 \\
\hline Familial history of psychiatric disorder & 0.012 & 3.495 & 1.316 & 9.283 \\
\hline Poor communication with the spouse & 0.041 & 2.802 & 1.044 & 7.520 \\
\hline Spouse's employment status & 0.003 & 2.861 & 1.434 & 5.708 \\
\hline History of psychiatric disorders during previous birth & 0.037 & 11.695 & 1.162 & -117.714 \\
\hline Lack of regular follow-up during pregnancy & 0.002 & 14.776 & 2.605 & -83.822 \\
\hline Lack of a helper in baby care & 0.042 & 2.656 & 1.038 & 6.796 \\
\hline Constant & 0.894 & 1.532 & & \\
\hline
\end{tabular}

Independent variable: Individuals at risk of postpartum depression; Nagelkerke $\mathrm{R}^{2}=0.435$

\section{Discussion}

About one in seven mothers included in the present study had an increased risk of developing depression. A review of the relevant studies conducted in other countries suggested that the frequency of PPD was distributed in a wide range from $0.6 \%$ to $60.8 \%$. In general, it was reported that approximately one in 7-10 mothers in the world had an increased risk of PPD [11-13].

The relevant studies in Turkey on postpartum depression reported the frequency of PPD in the range of 10\% to $40 \%$. A 2018 study by Sunay et al. performed in Malatya Province and published in 2021, investigated 381 mothers with babies aged between 0 and 3 months and reported that $14.2 \%$ of the women were at risk of PPD [14]. A study by Baser on 511 mothers with infants aged between 0 and 2 years in Ankara reported in 2018 that $19.90 \%$ of women had a risk of developing PPD [15]. In 2015, Kabakcioglu investigated the risk factors for PPD in 195 mothers with children aged between 0 and 12 months in Samsun and reported that the frequency of PPD risk was $22.6 \%$ [16]. Upon a review of the relevant studies conducted in Turkey, it was seen that the frequency of PPD varied by the region, where the study was carried out, the design of the study, the time after delivery, and the characteristics of the participants.

History of psychiatric disorders is one of the most important risk factors associated with the risk of developing postpartum depression in the present study. In a recent compendium, Mughai et al. suggested that the history of psychiatric disorders significantly increased the risk of PPD [17]. It was reported in a meta-analysis that women with a history of personal major depressive period had a 30\% higher risk of developing PPD [18]. In this context, preventive measures for PPD development may include taking detailed anamneses of expectant mothers, informing women and their relatives with a history of psychiatric disorders in that respect and providing access to psychological or medical support, if necessary.

The familial history of psychiatric disorders was also an important risk factor for PPD. In the present study, the risk of PPD in women with a familial history of psychiatric disorders was statistically significantly higher. Fiala et al. reported in a study, which investigated the variables affecting PPD risk in 3233 mothers in the Czech Republic, that both father and mother having a history of depression increased the risk of PPD and suggested in their multivariate analysis that having a history of depression only on the father's side was one of the most important risk factors for PPD [19]. Kimmel et al. reported in their study, which investigated the relationship between PPD risk and family history of psychiatric disorders, that $53.3 \%$ of mothers, who developed PPD, and $11.8 \%$ of mothers, who did not develop PPD, had a remarkable family history. As a result of their studies, they underlined that the risk of PPD might have increased in expectant mothers with a family history of psychiatric disorders, due to both the genetic characteristics and the effects of having been raised in the environment shaped by familial habits [6]. 
The World Health Organization (WHO) recommended that pregnant women should be monitored during at least four occasions and that prenatal care could be offered at regular intervals, based on the risk status of pregnancy and the time to estimated date of delivery [20]. It is important to have regular health checks and to be conscious of healthy behaviors in order to provide early diagnosis and early treatment, regardless of the type of disease. Xie et al. found in their study that regular monitoring of women prior to childbirth and providing support, where necessary, significantly reduced the risk of PPD [21]. In the study, the relationship between regular follow-up status and PPD development of pregnant women was investigated pursuant to the recommendations of WHO, and it was seen that lack of regular follow-ups during pregnancy statistically significantly increased the risk of PPD development, notwithstanding the other variables. Regular follow-up during pregnancy may be effective in preventing increased clinical severity and reducing the risk of developing PPD by receiving appropriate support or treatment for early depression findings.

Another variable which was found to have independently increased the risk of developing PPD in mothers was the poor communication between the mother and her partner. It was suggested in a study by Aydin et al. that the lack of spouse support increased the risk of PPD development by 1.9 times [22]. The parameters attributed to communication with the spouse, and which are the risk factors for PPD, include problems in marriage, poor support and marital bonding in marriage, inadequate spouse support in general, having an unhappy marriage, and communication problems with the spouse and his family [23,24].

In the present study, the risk of developing PPD was reduced in cases where the spouse had a regular employment. Meta-analyses published in 2008 indicated that lower socioeconomic and income levels were among the most important risk factors for PPD [25,26]. Segre et al. reported that women with higher income levels $(\$ 70,000$ per year) were four times less likely to develop PPD compared to lower-income women $(\$ 10,000$ per year) [27]. Our study found that having someone, who helps mothers with baby care, statistically significantly reduces the risk of developing PPD regardless of other variables. Xie et al. suggested that provision of support to the mother in baby care by any member of the family significantly reduced the risk of developing PPD [28]. It was reported that a lack support by the spouse, friends and family could prove to be a negative factor associated with an elevated risk of developing PPD [29]. In large families, in case the care of the baby was also assumed by another member of the family, this could reduce the burden of the mother. At the same time, the elders sharing their own experiences in baby care and providing emotional support can have a positive effect on PPD [29,30]. Providing the couples, who are planning to have a child or pregnant women and their families with information and increasing their awareness as regards provision of support for baby care during the postpartum period may reduce the risk of developing PPD.

\section{Limitations}

The present study has several limitations. The study was designed as a cross-sectional research and only the depressive symptoms of the participants during the study were taken into consideration. On the grounds that the mothers were not regularly monitored for symptoms of depression during pregnancy and after childbirth based on a prospective study design, the temporal relationship between the time of emergence of the symptom and the time of the occurrence of the risk factor could not be investigated.

\section{Conclusion}

The present study with a significant number of participants $(n=302)$ indicated that approximately one in seven mothers $(14.6 \%)$ with babies aging between 1-18 months had a risk of developing depression. An investigation of the parameters, which were considered to be effective in the emergence of this very high risk, indicated that the high risk factors for PPD included personal history of psychiatric disorders, familial history of psychiatric disorders, poor communication with the partner, spouse's lack of regular employment partner, history of psychiatric disorders at previous birth, lack of regular follow-ups during pregnancy and lack of someone, who helped with baby care $(\mathrm{p}<0.05)$.

Identifying pregnancies at risk of PPD in an earlier period, raising required awareness in the family, and taking measures against these risk factors may minimize the undesirable consequences of this quite prevalent problem. In particular, the practices that may reduce the risk of PPD include regular follow-up by primary healthcare services of the pregnancies of the women with a personal or familial history of psychiatric disorders or with psychiatric problems during their previous birth, questioning their family relationships during this process, referring them to a psychologist, psychiatrist or family counselor if necessary and offering postpartum family support to mothers in baby care.

Conflict of Interest: In our study, the authors had no conflict of interest.

\begin{tabular}{|l|r|l|}
\hline \multicolumn{2}{|c|}{ Author Contributions } & \multicolumn{1}{c|}{ Author Initials } \\
\hline SCD & Study Conception and Design & GP, YAG \\
\hline AD & Acquisition of Data & GP \\
\hline AID & Analysis and Interpretation of Data & GP, YAG \\
\hline DM & Drafting of Manuscript & GP \\
\hline CR & Critical Revision & GP, YAG \\
\hline
\end{tabular}

Financial Support: No financial support was received for the study.

Previous Publication: This article was translated from the thesis of the responsible author, titled as Postpartum Depression Frequency and Accompanying Factors, which was accepted in 2021, at Firat Family Health Center No. 12 in Izmir Buca. It has not been published in any journal and has not been presented as a paper. 


\section{References}

1. Committee on Obstetric Practice. The American College of Obstetricians and Gynecologists Committee Opinion no. 630. Screening for perinatal depression. Obstet Gynecol. 2015;125(5):1268-71. https://doi.org/10.1097/01.aog.0000465192.34779.dc

2. Wisner KL, Sit DK, McShea MC, Rizzo DM, Zoretich RA, Hughes CL, et al. Onset timing, thoughts of self-harm, and diagnoses in postpartum women with screen-positive depression findings. JAMA Psychiatry. 2013;70(5):490-8. https://doi.org/10.1001/jamapsychiatry.2013.87

3. Robertson E, Grace S, Wallington T, et al. Antenatal risk factors for postpartum depression: a synthesis of recent literature. Gen Hosp Psychiatry. 2004;26(4):289-95. https://doi.org/10.1016/i.genhosppsych.2004.02.006

4. Beck CT. Predictors of postpartum depression: an update. Nurs Res. 2001;50(5):275-85. https://doi.org/10.1097/00006199-200109000$\underline{00004}$

5. Erdogan A, Hocaoglu C. Diagnosis and treatment of postpartum depression: a review. MKU J Med. 2020;11(39):31-7. https://doi.org/10.17944/mkutfd.584854

6. Kimmel M, Hess E, Roy PS. Family history, not lack of medication use, is associated with the development of postpartum depression in a high-risk sample. Arch Womens Ment Health. 2015;18(1):113-21. https://doi.org/10.1007/s00737-014-0432-9

7. Gaillard A, Le Strat Y, Mandelbrot L, et al. Predictors of postpartum depression: prospective study of 264 women followed during pregnancy and postpartum. Psychiatry Res. 2014;215(2):341-6. https://doi.org/10.1016/j.psychres.2013.10.003

8. Davanzo R, Copertino M, DeCunto A, et al. Antidepressant drugs and breastfeeding: a review of the literature. Breastfeed Med. 2011;6(2):8998. https://doi.org/10.1089/bfm.2010.0019

9. Learman LA. Screening for depression in pregnancy and the postpartum period. Clin Obstet Gynecol. 2018 Sep;61(3):525-32. https://doi.org/10.1097/grf.0000000000000359

10. Lakkis NA, Mahmassani DM. Screening instruments for depression in primary care: a concise review for clinicians. Postgrad Med. 2015;127(1):99-106. https://doi.org/10.1080/00325481.2015.992721

11. Chamgurdani FK, Barkin JL, Curry CL, Mirghafourvand M. Comparison of maternal functioning between Iranian mothers and without depressive symptoms: a case-control study. J Environ Res Public Health 2020;17(10): 3350. https://doi.org/10.3390/ijerph17103350

12. Pocan AG, Erden O, Parlakgumus AH, Gereklioglu C, Dolgun AB. The incidence of and risk factors for postpartum depression at an urban maternity clinic in Turkey. Int J Psychiatry Med 2013; 46(2):179-94. https://doi.org/10.2190/pm.46.2.e

13. Yucesoy G, Ozkan S, Yildiz M, Cakiroglu Y, Bodur H. Postpartum depression: Prevalence and contributing risk factors. Turk Clin J Gynecol Obst 2011; 21(1): 6-12. https://www.jcog.com.tr/article/postpartum-depression-prevalence-and-contributing-risk-factors-59648.html

14. Sunay Z, Okyay EK, Gokbulut N, Ucar T. The relationship of postpartum depression with personality traits. Inonu Univ J Vocational School Health Serv. 2021;9(1):219-29. https://doi.org/10.33715/inonusaglik.813014

15. Baser DA. The evaluation of the relationship between postpartum depression and breastfeeding. Ankara Med J. 2018;18(3):276-85. https://doi.org/10.17098/amj.461652

16. Kabakcioglu F. Prevalence of depression, risk factors and social support level in mothers with 0-12 months old babies who applied to Nineteen May University Faculty of Medicine, Department of Family Medicine Clinic. Samsun Ondokuz Mayıs University Faculty of Medicine. 2015. http://libra.omu.edu.tr/tezler/87047.pdf (Accessed March 2, 2022)

17. Mughai S, Azhar Y, Siddiqui W. Postpartum Depression. In: StatPearls [Internet]. Treasure Island (FL): StatPearls Publishing; 2021 Jan. Available from: https://www.ncbi.nlm.nih.gov/books/NBK519070

18. Beck CT. A meta-analysis of predictors of postpartum depression. Nurs Res. 1996;45(5):297-303. https://doi.org/10.1097/00006199199609000-00008

19. Faila A, Svancara J, Klanova J, Kasparek T. Sociodemographic and delivery risk factors for developing postpartum depression in a sample of 3233 mothers from the Czech ELSPAC study. BMC Psychiatry. 2017;21;17(1):104. https://doi.org/10.1186/s12888-017-1261-y

20. World Health Organization. Antenatal care coverage - at least four visits (\%). https://www.who.int/data/gho/indicator-metadata-registry/imrdetails/80 (Access Date: 02 March 2022)

21. Xie RH, He G, Koszycki D, et al. Prenatal social support, postnatal social support, and postpartum depression. Annals of epidemiology. 2009;19(9):637-43. https://doi.org/10.1016/j.annepidem.2009.03.008

22. Aydin N, Inandi T, Karabulut N. Depression and associated factors among women within their first postnatal year in Erzurum province in eastern Turkey. Women Health 2005;41(2):1-12. https://doi.org/10.1300/j013v41n02_01

23. Gumus AB, Keskin G, Alp N, Ozyar S KA. The prevalence of postpartum depression and associated. Variables. New Symposium J. 2012;50(3):145-54. https://neuropsychiatricinvestigation.org/en/the-prevalence-of-postpartum-depression-and-associated-variables-16798 (Access Date: 02 March 2022)

24. Unterman RR, Posner NA, Williams KN. Postpartum Depressive Disorders: Changing Trends. Birth 1990;17(3):131-7. https://doi.org/10.1111/j.1523-536x.1990.tb00717.x

25. Karacam Z, Kitis Y. The postpartum depression screening scale: Its reliability and validity for the Turkish population. Turk J Psyc. 2008; 19(2): 187-96. https://toad.halileksi.net/sites/default/files/pdf/the-postpartum-depression-screening-scale-toad.pdf (Access Date: 02 March 2022)

26. Ege E, Timur S, Zincir H, Geckil E, Sunar B-Reeder. Social support and symptoms of postpartum depression among new mothers in Eastern Turkey. J Obstet Gynaecol Res 2008; 34 (4): 585-93. https://doi.org/10.1111/j.1447-0756.2008.00718.X

27. Segre LS, O'Hara MW, Arndt S, Stuart S. The prevalence of postpartum depression: the relative significance of three social status indices. Soc Psychiatry Psychiatr Epidemiol.2007;42(4):316-21. https://doi.org/10.1007/s00127-007-0168-1

28. Xie RH, Yang J, Liao S, et al. Prenatal family support, postnatal family support and postpartum depression. Aust New Zealand J Obst Gynaecol. 2010;50(4):340-5. https://doi.org/10.1111/j.1479-828x.2010.01185.x

29. Honjo K, Kimura T, Baba S, Ikehara S, Kitano N, Sato T, et al. Association between family members and risk of postpartum depression in Japan: Who do they live with" matter? -The Japan environment and children's study. Soc Sci Med 2018; 217:65-72. https://doi.org/10.1016/j.socscimed.2018.09.043

30. Yildirim A, Hacihasanoglu R, Karakurt P. The relationship between postpartum depression and social support and affecting factors. Int J Human Sci. 2011;8(1):31-46 https://www.j-humansciences.com/ojs/index.php/IJHS/article/download/1013/645 